УДК 621.31

I.B. Притискач, канд. техн. наук, ст. викл., ORCID 0000-0002-1892-0054

B.O. Оникійчук, магістрант, ORCID 0000-0002-0709-9344

Національний технічний університет України «Київський політехнічний інститут імені Ігоря Сікорського»

\title{
АНАЛІЗ ТА ОПТИМІЗАЦІЯ РЕЖИМІВ РОБОТИ ІНТЕГРОВАНИХ СИСТЕМ КОМПЛЕКСНОГО ЕНЕРГОЗАБЕЗПЕЧЕННЯ СПОЖИВАЧІВ ІЗ УРАХУВАННЯМ ЕКОНОМІЧНИХ ТА ЕКОЛОГІЧНИХ ФАКТОРІВ
}

\begin{abstract}
Представлено модель системи комплексного енергозабезпечення споживачів, $y$ вигляд енергетичного хабу, який забезпечує потребу споживачів у електричній та тепловій енергії. Модель передбачає врахування трьох потоків енергї̈ на вході: електрична енергія, природний газ та гаряча вода. До складу енергетичного хабу входять когенерачійна установка та накопичувачі електричної та теплової енергії. Запропоновано мультикритеріальний підхід до оптимізації режимів роботи розглянутої системи енергозабезпечення. Результати моделювання із використанням даних про навантаження спожсиачів та параметри енергоустановок вказують на доцільність застосування запропонованого підходу для визначення оптимальних значень погодинного споживання енергоресурсів в розглянутій системі.

Ключові слова: інтегрована система енергопостачання, розосереджена генерація, мінімізація витрат, когенераційна технологія, енергетичний хаб.
\end{abstract}

Вступ. Для багатьох країн енергетична безпека є однією з найбільш важливих областей економічної безпеки. Глобальна енергетична криза у зв'язку зі скороченням світових запасів нафти і газу, постійне зростання цін на енергоресурси та негативний вплив від спалювання викопного палива на зміну клімату, призвели до підвищеної зацікавленості світової економіки у збільшенні виробництва та використання альтернативних і поновлюваних джерел енергії. Розвиток нетрадиційних та відновлюваних джерел енергії слід розглядати як важливий фактор підвищення енергетичної безпеки. Масштабне використання потенціалу таких джерел енергії в Україні є не тільки національним пріоритетом, але має також значне міжнародне значення як важливий фактор протидії глобальним змінам клімату, що покращує загальний стан енергетичної безпеки в Європі. Саме тому, підвищення рівня використання альтернативних (нетрадиційних та поновлюваних) джерел енергії та палива є одним 3 основних напрямків реалізації державної політики енергозбереження України.

3'являється потреба у забезпеченні ефективного функціонування нетрадиційних та відновлюваних джерел енергії та їх інтеграції до існуючих енергосистем. Концепція інтегрованої енергопостачальної системи полягає у поєднанні елементів енергетичної інфраструктури, зокрема пов'язаних із забезпеченням споживачів електроенергією та теплом, тим самим забезпечуючи обмін потужністю між раніше розділеними системами. Інтегрованої енергопостачальна система забезпечує функції отримання, постачання, перетворення та зберігання різних видів енергії. Концепція інтегрованої енергопостачальної системи використовує поняття «енергетичних хабів», які можна розглядати як узагальнення поняття мережевих вузлів в традиційних електричних мережах на більшу кількість видів енергоносіїв із врахуванням можливості їх взаємного перетворення. Розроблення та впровадження підходів до оптимізації функціонування таких енергетичних хабів $є$ перспективним питанням у контексті сталого розвитку енергетики України, залучення нових інвестицій у нетрадиційні та відновлювані джерела енергії, стимулювання діяльності активного споживача, забезпечення нормативної якості електроенергії, реалізації концепції Smart Grid.

Проблемам дослідження інтегрованих енергопостачальних систем в цілому, і енергетичних хабів зокрема, присвячено численні дослідження вітчизняних і закордонних вчених. Основні засади концепції «енергетичного хабу» розглянуто в [1]. Впровадження таких комбінованих багатогенераційних систем може призвести до значного підвищення енергоефективності, зменшення викидів CO2 та економії коштів у процесі забезпечення кінцевих споживачів енергоресурсами. У цьому напрямку наукове співтовариство розглядає аналіз та планування розподіленої генерації з широкомасштабними підходами з урахуванням технічних, екологічних, економічних та соціальних питань [2-3].

(C) І.В. Притискач, В.О. Оникійчук, 2018 


\section{ISSN 1813-5420 (Print). Енергетика: економіка, технології, екологія. 2018. № 1}

Як визначено в [4], енергетичний хаб є інтегрованою систему з кількома видами енергоносіїв, і яка поєднує технології виробництва, перетворення та зберігання енергії, зокрема нетрадиційні та відновлювані джерела енергії та накопичувачі енергії, для забезпечення кінцевих споживачів електроенергією, теплом, холодом та іншими видами енергоносіїв [5]. Значна кількість сучасних досліджень присвячена визначенню характеристик, плануванню, оцінюванню та оптимізації енергетичних хабів [6-8].

Проблема експлуатації енергетичних хабів полягає в тому, щоб забезпечити оптимальний вибір компонентів енергетичних хабів та забезпечити їх об'єднання в одну систему. Досліджуючи потоки різних енергоносіїв виконують аналіз взаємодії між джерелами генерації енергії та кінцевими споживачами [9]. Для визначення оптимальних рівнів витрат на придбання енергоносіїв важливою є задача оперативного планування роботи різних елементів енергетичного хабу, що вирішується на оперативному горизонті часу.

Мета та завдання. Метою дослідження $є$ вивчення можливостей ефективного використання енергії в інтегрованих енергопостачальних системах, а також розробка та вдосконалення моделей мультикритеріального планування та оптимізації режимів роботи інтегрованих систем комплексного енергозабезпечення споживачів із урахуванням економічних та екологічних факторів. Для досягнення поставленої мети в роботі були сформульовані та вирішені наступні завдання: аналіз сучасного стану та технічного рівня обладнання і технологій комплексного енергозабезпечення споживачів в світі і Україні; аналіз проблеми експлуатації енергетичних хабів, які включають засоби розосередженої генерації та накопичувачі енергії; розробка моделі забезпечення оптимального режиму споживання та генерування різних видів енергоресурсів із застосуванням наявних джерел енергії.

Матеріал і результати досліджень. До складу енергетичного хабу, з точки зору функціональності, можуть входити три основних види елементів: прямі з'єднання, перетворювачі енергії та накопичувачі енергії.

Прямі з'єднання використовуються для доставки вхідного енергоносія до виходу без перетворення його в іншу форму енергії та без суттєвої зміни його параметрів (наприклад, електричної напруги, тиску газу тощо). Прикладами цього типу елементів можуть бути лінії електропередачі та трубопроводи.

Перетворювачі енергії використовуються для перетворення енергії в інші форми або для зміни параметрів енергоносія. Прикладами є парові і газові турбіни, електричні машини, паливні елементи, електролізери, термоелектричні перетворювачі тощо. Компресори, насоси, трансформатори, силові електронні інвертори також відносяться до перетворювачів енергії. Третій тип елемента використовується для зберігання енергії. До цього виду елементів відносяться, наприклад, електричні акумулятори.

Одним із основних елементів енергетичного хабу є об'єкти розосередженої генерації. В багатьох країнах світу в даний час, поряд із розвитком централізованого енергопостачання, все більш активно підтримується тенденція широкомасштабного переходу до розосередженої генерації.

Існують різні підходи до визначення поняття розосередженої генерації енергії. У ряді випадків термін «розосереджена генерація енергії» використовується як синонім поняття генерації в децентралізованій енергосистемі для покриття потреб в енергії ізольованих (не підключених до магістральних мереж) споживачів.

Розосереджена генерація - це практика розміщення невеликих енергогенеруючих потужностей, близьких до точки кінцевого споживання.

Розподілена генерація має багато переваг, зокрема:

- скорочення витрат на електроенергію;

• підвищення надійності електропостачання;

- забезпечення можливості продажу електроенергії ;

- генерування екологічно чистої енергії.

Розосереджена генерація $є$ хорошим рішенням для багатьох цілей, оскільки елементи малої генерації є легко доступними, прості в установці та експлуатації, можуть бути переміщені оскільки $є$ модульними, і економічно ефективні.

Представимо модель функціонування інтегрованої системи комплексного енергозабезпечення, яка має на меті задовольнити потребу споживачів у електричній та тепловій енергії із максимальною ефективністю. Така система буде розглядатись як енергетичний хаб, який працює паралельно із існуючими централізованим системами електропостачання та теплопостачання. Основними енергоносіями, які споживаються в енергетичному хабі є електроенергія та тепло для житлових та громадських будівель, а також промислових об'єктів невеликої потужності. Електроенергія використовується для роботи систем освітлення, вентиляції побутових потреб, роботи технологічного обладнання. Тепло споживається у вигляді гарячої води. Для отримання цих енергоносіїв використовуються такі джерела: електроенергія може купуватися в енергосистеми та генеруватися на когенераційній установці; тепло одержується із централізованої системи та одержується на когенераційній установці. Споживачі енергетичного хабу сплачують за електроенергію за двозонним тарифом. Когенераційна установка працює на природному газі. Функціональна схема енергетичного хабу представлена на рис. 1. 


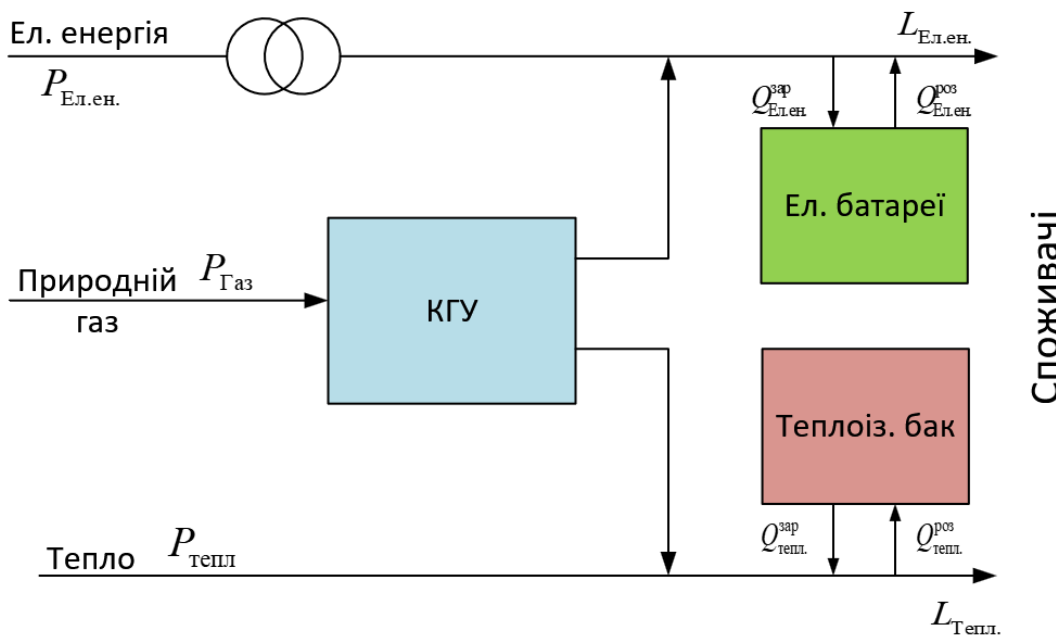

Рисунок 1 - Функціональна схема енергетичного хабу

Ціллю системи комплексного енергозабезпечення є такий режим іï функціонування, коли в повному обсязі забезпечуються потреби споживачів в енергоносіях при максимально ефективних фінансових показниках роботи, тобто мінімальних витратах на купівлю електроенергії, природного газу та тепла у енергопостачальних організації.

Згідно підходу, запропонованого у роботі [2], сформулюємо цільову функцію та обмеження оптимізаційної моделі. Цільова функція буде мати такий вигляд:

$$
\sum_{k=0}^{T-1}\left(c_{\text {Ел.ен. }}(k) P_{\text {Ел.ен. }}(k)+c_{\text {Тепл. }}(k) P_{\text {Тепл. }}(k)+c_{\text {Газ. }}(k) P_{\text {Газ. }}(k)\right) \rightarrow \min
$$

де $c_{\text {Ел.ен. }}(k), c_{\text {Тепл. }}(k), c_{\text {Газ. }}(k)$ - тарифи на електроенергію, тепло та газ на ринку за $k$-ий інтервал часу (годину), грн/кВт·год;

$P_{\text {Ел.ен. }}(k), P_{\text {Тепл. }}(k), P_{\text {Газ. }}(k)$ - обсяг покупки електроенергії, тепла та газу на ринку за $k$-ий інтервал часу (годину), кВт•год.

Крім економічного критерію, при визначенні оптимальних режимів функціонування енергетичного хабу, до уваги може бути взято екологічний критерій. У цьому випадку цільовою функцією може виступати мінімізація викидів CO2 при виробництві та транспортування енергії. Для нашого випадку, викиди при генеруванні електроенергії можуть бути розраховані із врахуванням національного значення коефіцієнта викидів СО2 для електроенергії згідно з частиною II [10], розробленому у 2013-2014 роках Об'єднаним Дослідницьким Центром Енергетики і Транспорту (Європейська Комісія), яке для України становить 0,924 кг/кВт·год. Аналогічним чином може бути визначений коефіцієнт для централізованого теплопостачання. Для випадку спалювання газу в когенераційній установці було прийнято середнє значення для такого типу обладнання.

Цільова функція для критерію мінімізації викидів СО2 буде мати такий вигляд:

$$
\alpha_{\text {Ел.ен. }} \sum_{k=0}^{T-1} P_{\text {Ел.ен. }}(k)+\alpha_{\text {Тепл. }} \sum_{k=0}^{T-1} P_{\text {Тепл. }}(k)+\alpha_{\text {Газ. }} \sum_{k=0}^{T-1} P_{\text {Газ. }}(k) \rightarrow \min
$$

де $\alpha_{\text {Ел.ен. }}, \alpha_{\text {Тепл. }}, \alpha_{\text {Газ. }}$ - питомі викиди на генерацію електроенергії та тепла в централізованих системах енергопостачання, а також викиди при спалюванні газу в когенераційній установці, кг/кВт·год.

Баланс надходження та споживання енергоресурсів задаємо у вигляді обмежень. Перетворення різних видів енергоресурсів представимо за допомогою метриці перетворення $\boldsymbol{\Theta}$. Також у рівняннях балансу враховано можливість накопичувати енергію (в електричних акумуляторах та теплоізольованих баках із гарячою водою). Із врахуванням підходів запропонованих у [2], обмеження мають вигляд: 


$$
\begin{aligned}
& \mathbf{E}(k+1)=\mathbf{E}(k)+\mathbf{A}^{3 a p} \mathbf{Q}^{3 a p}(k)-\mathbf{A}^{p o 3} \mathbf{Q}^{p o 3}(k)-\mathbf{E}_{L}, \\
& \mathbf{L}(k)=\mathbf{\Theta P}(k)-\mathbf{Q}^{3 a p}(k)+\mathbf{Q}^{p o 3}(k), \\
& \mathbf{P}(k)^{\min } \leq \mathbf{P}(k) \leq \mathbf{P}(k)^{\max }, \\
& 0 \leq Q_{i}^{3 a p}(k) \leq \delta_{i}^{3 a p}(k) Q_{i}^{\max }(k) \quad i=1, \ldots, M, \\
& 0 \leq Q_{i}^{p o 3}(k) \leq \delta_{i}^{p o 3}(k) Q_{i}^{\max }(k) \quad i=1, \ldots, M, \\
& \delta_{i}^{3 a p}(k)+\delta_{i}^{p o s}(k) \leq 1 \quad i=1, \ldots, M, \\
& \mathbf{E}(k)^{\min } \leq \mathbf{E}(k) \leq \mathbf{E}(k)^{\max }, \\
& \mathbf{E}_{0}=\mathbf{E}_{T}
\end{aligned}
$$

$\mathbf{P}$ - вектор-стовпець, що представляє вхідні енергетичні потоки (рівні споживання кожного енергоресурсу);

$\mathbf{L}$ - вектор-стовпець, що представляє вихідні енергетичні потоки (споживання);

$\boldsymbol{\Theta}$ - матриця перетворення типів енергії (містить 0 при неможливості перетворення або значення коефіцієнтів перетворення);

$\mathbf{P}^{\min }, \mathbf{P}^{\max }$ - вектори-стовпці, що представляють обмеження на мінімальні та максимальні рівні енергетичних потоків, визначається номінальною потужністю та навантажувальною здатністю елементів;

$\mathbf{Q}^{\text {заp }}, \mathbf{Q}^{p 03}$ - вектори-стовпці, що представляють обмін енергією з пристроями накопичення енергії;

$\mathbf{A}^{\text {заp }}, \mathbf{A}^{p o s}$ - діагональні матриці ККД накопичувачів різних видів енергії;

$\mathbf{E}$ - вектор, що містить рівень накопиченої енергії в накопичувачах;

$\mathbf{E}_{L}$ - вектор, що містить значення втрат енергії в накопичувачах за одиницю часу;

$\mathbf{E}_{0}-$ вектор, що містить рівень накопиченої енергії в накопичувачах в початковий момент часу для $k=0$;

$Q_{i}^{\max }$ - ємність накопичувачів енергії;

$\delta_{i}^{\text {зар }}, \delta_{i}^{p 0 з}$ - додаткові бінарні змінні, які введені для реалізації обмеження на неможливість одночасного накопичення і використання енергії з накопичувачів (неможливості заряду і розряду в одну одиницю часу).

Матриці, що входять в рівняння обмежень представимо таким чином

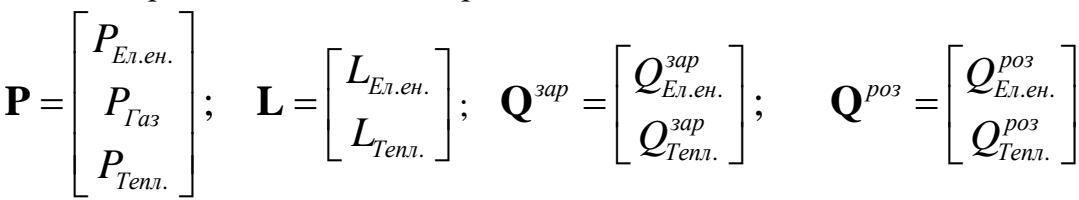

$$
\begin{aligned}
& \mathbf{A}^{\text {зар }}=\left[\begin{array}{cc}
\eta_{\text {Eл.ен. }}^{\text {sap }} & 0 \\
0 & \eta_{\text {mеnл. }}^{\text {sap }}
\end{array}\right] ; \quad \mathbf{A}^{\text {pos }}=\left[\begin{array}{cc}
\frac{1}{\eta_{\text {Eл.ен. }}^{\text {sap }}} & 0 \\
0 & \frac{1}{\eta_{\text {menл. }}^{\text {sap }}}
\end{array}\right] \\
& \boldsymbol{\Theta}=\left[\begin{array}{ccc}
\varpi_{\text {Ел.транс. }} & \varpi_{\text {Кгу }}^{\text {Елен. }} & 0 \\
0 & \varpi_{\text {КГу }}^{\text {Tепл. }} & \varpi_{Ц О}
\end{array}\right]
\end{aligned}
$$

Крім однокритеріальних цільових функцій розглянемо мультикритеріальний підхід до визначення оптимальних режимів функціонування енергетичного хабу. Задачу представимо у вигляді

$$
\begin{aligned}
& y \rightarrow \min , \\
& F_{1}(\mathbf{P})-w_{1} y \leq F_{1}^{*} \\
& F_{2}(\mathbf{P})-w_{2} y \leq F_{2}^{*}
\end{aligned}
$$




$$
F_{1}(\mathbf{P})=\sum_{k=0}^{T-1}\left(c_{\text {Ел.ен. }}(k) P_{\text {Ел.ен. }}(k)+c_{\text {Тепл. }}(k) P_{\text {Тепл. }}(k)+c_{\text {Газ. }}(k) P_{\text {Газ. }}(k)\right)
$$

- цільова функція за

економічним критерієм,

$$
F_{2}(\mathbf{P})=\alpha_{\text {Ел.ен. }} \sum_{k=0}^{T-1} P_{\text {Ел.ен. }}(k)+\alpha_{\text {Тепл. }} \sum_{k=0}^{T-1} P_{\text {Тепл. }}(k)+\alpha_{\text {Газ. }} \sum_{k=0}^{T-1} P_{\text {Газ. }}(k)
$$

екологічним критерієм,

$w_{1}, w_{2}$ - вагові коефіцієнти, які виражають міру відносних компромісів між цілями,

$F_{1}^{*}, F_{2}^{*}$ - значення, до яких ми прагнемо наближати результат цільових функцій.

Виконаємо чисельне моделювання розглянутого енергетичного хабу для оцінки особливостей результатів та адекватності моделі. Моделювання виконаємо для тривалості 24 години із дискретизацією 1 година. Такий сценарій можна розглядати типовим, оскільки в процесі функціонування енергетичного хабу можна накопичити досить представницьку статистику про особливості добових графіків навантаження споживачів підприємства та досить точно прогнозувати потребу в енергоресурсах на наступну добу.

Для моделювання були використані типові графіки споживання електроенергії та тепла в системі гарячого водопостачання для змішаного побутового та промислового навантаження.

Значення коефіцієнтів перетворення енергії та максимальні значення потужності енергоустановок представлені в таблиці 1.

Смність електричних акумуляторних батарей прийнята рівною 500 кВт·год, а обсяг теплової енергії, який можна запасати у теплоізольованому баку із гарячою водою, становить 1000 кВт•год.

\begin{tabular}{|c|c|c|c|}
\hline \multicolumn{4}{|c|}{ Значення коефіціснтів у матриці перетворення енергії } \\
\hline & Енергосистема & КГУ & $\begin{array}{c}\text { Система гарячого } \\
\text { водопостачання }\end{array}$ \\
\hline Електрична енергія & 0.94 & 0.3 & 0 \\
\hline Тепло & 0 & 0.4 & 0.9 \\
\hline \multicolumn{4}{|c|}{ Максимальні значення потужностей енергоустановок } \\
\hline Трансформатор, кВА & КГУ, кВТ & \multicolumn{2}{|c|}{$\begin{array}{c}\text { 3’єднання з системою гарячого } \\
\text { водопостачання, кВт }\end{array}$} \\
\hline 630 & 350 & \multicolumn{2}{|c|}{1000} \\
\hline
\end{tabular}

Таблиця 1 - Значення параметрів, використані у розрахунку

Безпосередньо моделювання оптимізаційних задач виконувалося із використанням пакету Optimization Toolbox середовища MATLAB.

Результати розрахунків представлені на рисунках 2-6. Варіант а відповідає використанню економічного критерію, б екологічного критерію, в - мультикретиріальний підхід. На рисунках 7-8 додатні значення відповідають накопиченню енергії, а від’ємні - споживанню енергії із акумуляторів.

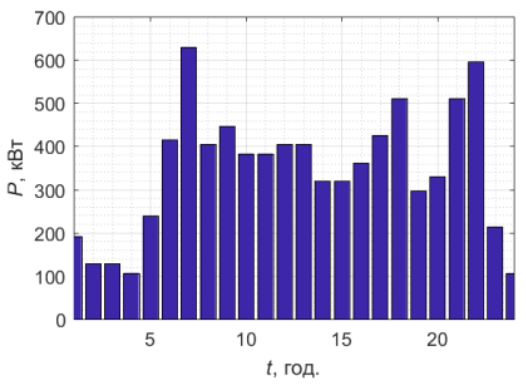

a

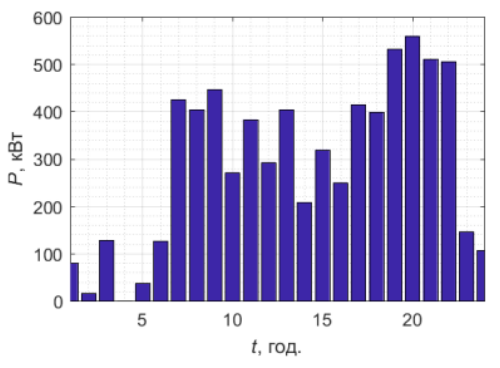

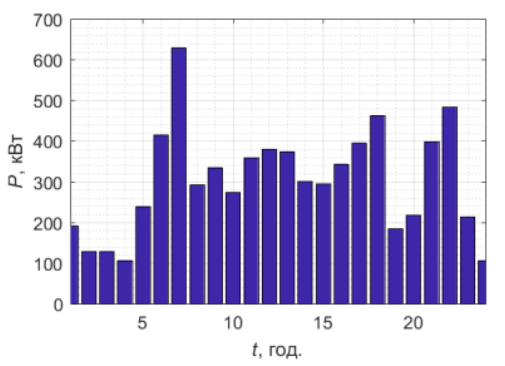

Рисунок 2 - Споживання електроенергії із енергосистеми 


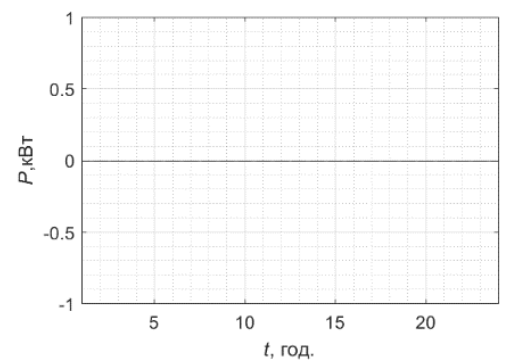

$\mathbf{a}$

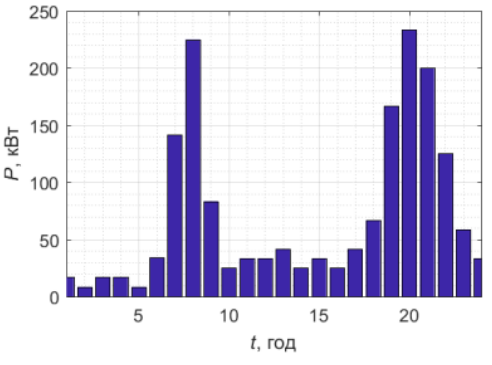

a

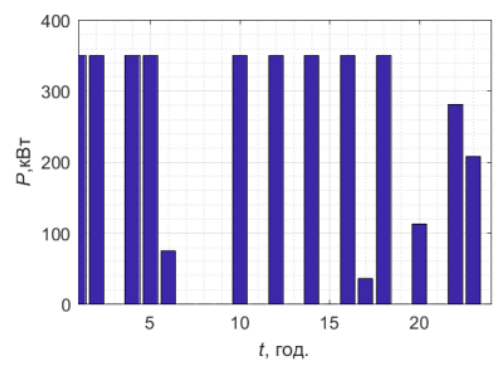

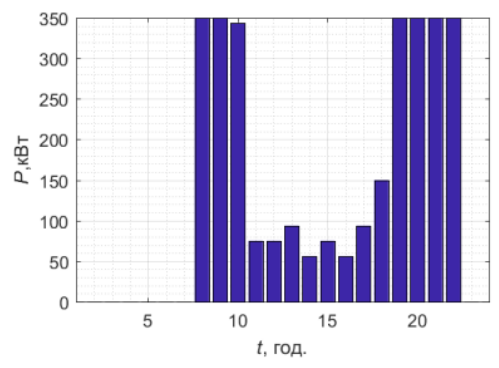

Рисунок 3 - Продуктивність КГУ
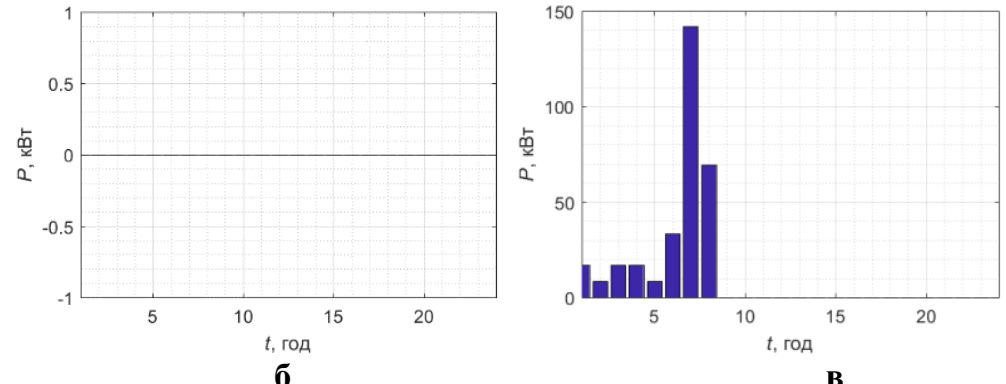

Рисунок 4 - Споживання потужності із системи гарячого водопостачання

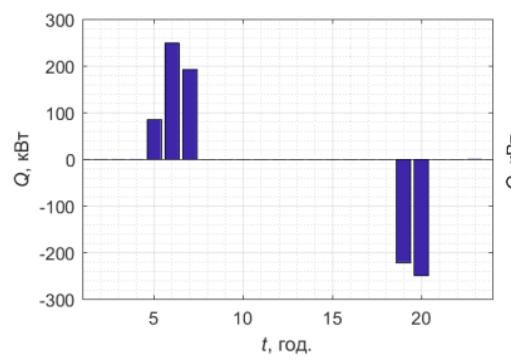

$\mathbf{a}$

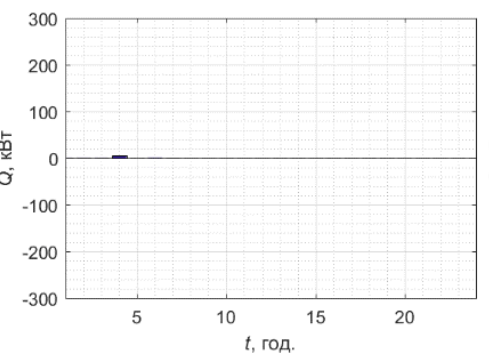

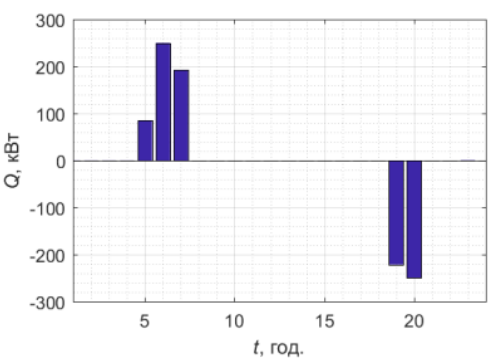

B

Рисунок 5 - Обмін енергією із електричними акумуляторами

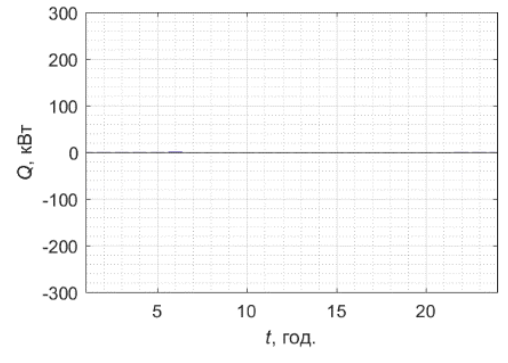

a

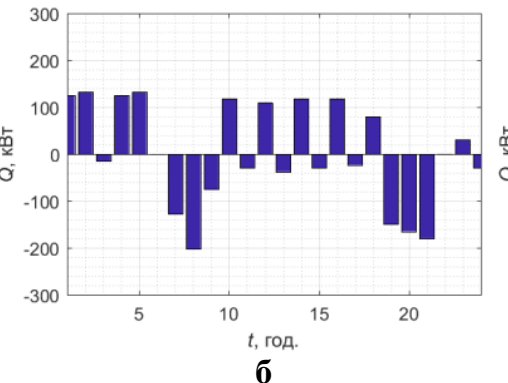

б

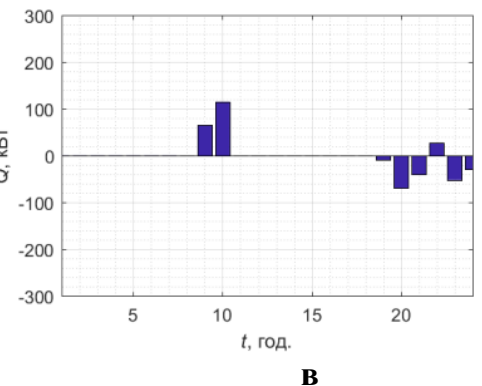

B

Рисунок 6 - Обмін енергією із накопичувачем гарячої води

Як видно із графіків, для різних критеріїв спостерігається дещо різний профіль споживання електроенергії із мережі. Також видно, що для першого критерію робота когенераційної установки виявилася неефективною протягом всієї доби. Режими роботи накопичувачів електричної та теплової енергії також виявився різним. Видно, що для варіанту застосування економічного критерію та мультикритеріальної оптимізації відбувається активне накопичення електроенергії в години доби із низьким тарифом і споживання в години максимальних навантажень. Для сценарію тільки екологічного критерію застосування акумуляторів електроенергії взагалі виявилося непотрібним. Це ж стосується застосування накопичувачів гарячої води для варіанту використання економічного критерію.

Значення цільових функцій, які одержані для різних варіантів, представлено у таблиці 3. 
ISSN 1813-5420 (Print). Енергетика: економіка, технології, екологія. 2018. № 1

Таблиця 3 - Значення коефіцієнтів у матриці перетворення енергії

\begin{tabular}{|c|c|c|c|}
\hline & Економічний критерій & $\begin{array}{c}\text { Екологічний } \\
\text { критерій }\end{array}$ & $\begin{array}{c}\text { Мультикритеріальна } \\
\text { оптимізація }\end{array}$ \\
\hline Витрати коштів, грн/доба & 14024 & 14960 & 14095 \\
\hline Викиди СО2, кг/доба & 8097 & 7216 & 7422 \\
\hline
\end{tabular}

Як видно 3 таблиці 3, при використанні економічного критерію викиди СО2 значно більші від мінімально досяжного значення. Аналогічно, для екологічного критерію витрати коштів на 6,5\% більші за оптимальні. В той же час спільне використання двох критеріїв дає змогу досягти ефективного компромісу, за якого витрати всього на 0,5\% більші за оптимальні, при викидах СО2 близьких до мінімальних.

Висновки.

Запропоновано мультикритеріальний підхід до планування та оптимізації режимів роботи систем комплексного енергозабезпечення споживачів із джерелами розосередженої генерації та накопичувачами енергії, який дає змогу підвищити ефективність функціонування таких систем. За результатами моделювання на прикладі енергетичного хабу із трьома видами енергоносіїв показано, що даний метод підходить для планування погодинного споживання електричної енергії, природного газу та гарячої води, при компромісі з точки зору мінімальних витратах на дані енергоресурси та викиди СО2.

\section{Список використаної літератури}

1. Energy hubs for the future / Geidl M., Koeppel G., Favre-Perrod P., Klockl B.. // IEEE Power and Energy Magazine. - 2007. - №1. - C. 24-30.

2. Parisio A. A robust optimization approach to energy hub management / Parisio A., Del Vecchio C., Vaccaro A.. // International Journal of Electrical Power \& Energy Systems. - 2012. - №42. - C. 98-104.

3. Chicco, G. Distributed multigeneration: A comprehensive view / Chicco, G., Mancarella P.. // Renewable and Sustainable Energy Reviews. - 2009. - №3. - C. 535-551.

4. Geidl M. Integrated modeling and optimization of multi-carrier energy systems / Geidl M.. // ETH Zurikh: Power Systems Laboratory. - 2007.

5. Brahman F. Optimal electrical and thermal energy management of a residential energy hub, integrating demand response and energy storage system / Brahman F., Honarmand M., Jadid S. // Energy and Buildings. 2015. - №90.

6. Anders, G. Innovations in power systems reliability / Anders, G., Vaccaro A.. // Springer Series in Reliability Engineering. - 2011. - №1. - C. 361-375.

7. Krause T. Multiple-Energy Carriers: Modeling of Production, Delivery, and Consumption / Krause T., G. Andersson K. Fröhlich A. Vaccaro. // Proceedings of the IEEE. - 2007. - №1 . - C. 15-27.

8. Analysis of the results of optimal energy consumption planning for residential complex energy hub / Ю.Веремійчук, I. Притискач, О. Ярмолюк та ін.]. // IEEE 58th International Scientific Conference on Power and Electrical Engineering of Riga Technical University (RTUCON). - 2017. - №10. - C. 12-13.

9. Energy hub function optimization models during ukrainian energy resources market liberalization / Ю.Веремійчук, І. Притискач, О. Ярмолюк, В. Опришко. // Scientific Journal of Riga Technical University, Power and Electrical Engineering. - 2017. - №34. - C. 14-17.

10. Gabrielaitiene I. Как разработать «План действий по устойчивому энергетическому развитию (ПДУЭР) в городах восточного партнерства и центральной Азии» / Gabrielaitiene I., Melica G., Bertoldi P.. // JRS sciece and policy report JRC 90401. - 2014. - №10.

I. Prytyskach, Cand. Sc. (Eng.), Assis. Prof., ORCID 0000-0002-1892-0054

V. Onikiychuk, Msc. ORCID 0000-0002-0709-9344 National Technical University of Ukraine «Igor Sikorsky Kyiv Polytechnic Institute»

\section{ANALYSIS AND OPTIMIZATION OF COMPLEX ENERGY SUPPLY INTEGRATED SYSTEMS WITH CONSIDERATION OF ECONOMIC AND ENVIRONMENTAL FACTORS}

The model of complex energy supply system of consumers is presented, in the form of an energy hub, which ensures the need of consumers in electric and thermal energy. The model includes taking into account three streams of energy at the input: electric energy, natural gas and hot water. The ergy hub includes a cogeneration 
unit, storage units for electric and thermal energy. Multi-criteria approach for optimizing the operating modes of the considered energy supply system is proposed. Simulation results using data on load of consumers and parameters of power plants indicate the expediency of the proposed approach to determine the optimal values of hourly energy consumption in the considered system.

Keywords: integrated power distribution systems, distributed generation, active consumer, cogeneration technology, energy hub.

\section{References References}

[1] Geidl, M., "Energy hubs for the future", in IEEE Power and Energy Magazine, Geidl, M., ., G. Koeppel, Favre-Perrod P., Klockl B., G. Andersson, and K. Frohlich, 2007, pp. 24-30.

[2] Parisio, A., "A robust optimization approach to energy hub management", in International Journal of Electrical Power \& Energy Systems, Parisio, A., C. Del Vecchio, and A. Vaccaro, 2012, pp. 98-104.

[3] Chicco, G., "Distributed multigeneration: A comprehensive view", in Renewable and Sustainable Energy Reviews, Chicco, G. and P. Mancarella, 2009, pp. 535-551.

[4] Geidl, M., "Integrated modeling and optimization of multi-carrier energy systems" in ETH Zurikh: Power Systems Laboratory, 2007.

[5] Brahman, F., "Optimal electrical and thermal energy management of a residential energy hub, integrating demand response and energy storage system”, in Energy and Buildings, Brahman F., Honarmand M., Jadid S., 2015, pp. 65-75.

[6] Anders, G.," Innovations in power systems reliability", in XVI: 361 of Springer series in reliability engineering, Anders, G., Vaccaro A.., 2011.

[7] Krause, T., "Multiple-Energy Carriers: Modeling of Production, Delivery, and Consumption",in Proceedings of the IEEE, Krause T., G. Andersson K. Fröhlich A. Vaccaro. , 2007, pp.15-27.

[8] Veremiichuk Y.," Analysis of the results of optimal energy consumption planning for residential complex energy hub", in 2017 IEEE 58th International Scientific Conference on Power and Electrical Engineering of Riga Technical University, Y. Veremiichuk, I. Prytyskach, O. Yarmoliuk, V. Opryshko,, 2017, pp. 12-13.

[9] Y. Veremiichuk, "Energy hub function optimization models during ukrainian energy resources market liberalization" in Scientific Journal of Riga Technical University, Power and Electrical Engineering, Y. Veremiichuk, I. Prytyskach, O. Yarmoliuk, V. Opryshko, 2017, pp. 14-17.

[10] Gabrielaitiene I." How to develop the "Action Plan for Sustainable Energy Development (SEAP) in the cities of the Eastern Partnership and Central Asia", in JRS sciece and policy report JRC 90401, Gabrielaitiene I., Melica G., Bertoldi P.,2014.

И.В. Прытыскач, канд. техн. наук, ст. преп., ORCID 0000-0002-1892-0054

B. Оникийчук, магистрант ORCID 0000-0002-0709-9344

Национальный технический университет Украины «Киевский политехнический институт имени Игоря Сикорского»

\section{АНАЛИЗ И ОПТИМИЗАЦИЯ РЕЖИМОВ РАБОТЫ ИНТЕГРИРОВАННЫХ СИСТЕМ КОМПЛЕКСНОГО ЭНЕРГООБЕСПЕЧЕНИЯ ПОТРЕБИТЕЛЕЙ С УЧЕТОМ ЭКОНОМИЧЕСКИХ И ЭКОЛОГИЧЕСКИХ ФАКТОРОВ}

Представлена модель системы комплексного энергообеспечения потребителей, в виде энергетического хаба, который обеспечивает потребителей электрической и тепловой энергией Модель предполагает учет трех потоков энергии на входе: электрическая энергия, природный газ и горячая вода. В состав энергетического хаба входят когенерационная установка и накопители электрической $и$ тепловой энергии. Предложен мультикритериальний подход $\kappa$ оптимизации режимов работь рассматриваемой системы энергообеспечения. Результаты моделирования с использованием данных о нагрузке потребителей и параметры энергоустановок указывают на иелесообразность применения предложенного подхода для определения оптимальных значений почасового потребления энергоресурсов в рассматриваемой системе.

Ключевые слова: интегрированная система энергоснабжения, распределённая генерация, минимизация расходов, когенерационная технология, энергетический хаб. 